\title{
LA FUNESTA INMEDIACIÓN: JORGE LUIS BORGES Y EL ANHELO DE UN SABER ABSOLUTO ${ }^{1}$
}

\author{
MARTÍN GRASSI \\ Pontificia Universidad Católica Argentina
}

\begin{abstract}
RESUMEN: La filosofía ha encontrado en la literatura de Jorge Luis Borges un ámbito único para reflexionar en torno de sus propios problemas. En este ensayo examinaré las tensiones y contradicciones que afloran dentro del paradigma metafísico de la inmediación y de la intuición. El cuento de «Funes, el memorioso» ofrece la ocasión para pensar en la imposibilidad del hombre de afirmar un sistema de signos o una facultad perceptiva que ignore el inexorable resto que guarde la diferencia entre lo real y lo representado. Una vida humana que se afirme en el ideal de un saber absoluto, de una visión ininterrumpida, es finalmente funesta. El hombre vive de las mediaciones y de las interrupciones, recuerda porque olvida, despierta porque sueña, conoce porque ignora: mira porque tiene párpados.
\end{abstract}

PALABRAS CLAVE: inmediación; presencia; resto; lenguaje; memoria; Borges.

\section{The deadly immediacy: Jorge Luis Borges and the longing for absolute knowledge}

ABSTRACT: Philosophy finds in Borges' literature a unique place to reflect on its own problems. In this essay, I shall examine the tensions and contradictions that arise from a metaphysical paradigm of immediacy and intuition. Reading the story «Funes, el memorioso», I will show that a system of signs and a perceptive faculty that ignores the necessary difference between the real and the representation is impossible for men. Human life is unhuman if it is affirmed in its ideal of an absolute knowledge, of an uninterrupted vision. Man live in between mediations and interruptions; human beings remember because they forget, awakens because they sleep, know because they ignore, look because their eyes have also eyelashes.

KEY WORDS: immediacy; presence; rest; language; memory; Borges.

\section{MEtÁfora, ARTIFICIO Y VERDAD}

El célebre cuento de Borges «Funes, el memorioso» es, según palabras del mismo autor, «una larga metáfora del insomnio»². Para comprender el sentido de esta descripción, debemos descifrar qué relación habría entre la memoria y el insomnio, o, a la inversa, entre el sueño y el olvido. El cuento de «Funes» está incluido en Artificios, y el título de dicha colección de cuentos no debiera pasar desapercibido. Podríamos, en una primera aproximación, considerar que la palabra artificio alude al género literario de los cuentos borgeanos, en los que la narración no se separa de su esencia fantástica. El cuento es, en grado sumo,

1 Agradezco profundamente la lectura previa, los comentarios y las correcciones de este ensayo hechas por el Dr. Mariano García y el Dr. Juan Torbidoni.

2 Borges, J. L. (2007), «Artificios», Prólogo, en: Obras completas. Buenos Aires: Emecé, t. I, p. 581. 
un «artificio», el producto de una operación artística que, por ello, obedece también a una técnica, a una producción metódica y calculada, y que busca producir nuevos sentidos y escenarios, extraños al registro de la realidad. Esta doble característica del artificio se relaciona con su sinónimo, «artificiosidad», que alude a «la falta de naturalidad derivada de una gran elaboración», o también, «al procedimiento o medio ingenioso para conseguir, encubrir o simular algo». Ambas acepciones del artificio confluyen en el prejuicio según el cual «lo natural», lo que pertenece a "la naturaleza» es lo verdadero, mientras que lo que es obra de la técnica es verdadero en sentido derivado, solo en tanto que imita o refleja lo natural. Cuando una obra, producto de la técnica, se sale de las exigencias de la mímesis, entonces decimos que es artificiosa, sea porque guarda una intención consciente de simular lo natural, o de persuadir por el engaño, o de encubrir lo verdadero, ya sea porque «lo técnico» vence a «lo verdadero", y la obra hace gala tan solo de los medios de su producción, y no de la verdad a la que debería apuntar. En suma, un artificio es una operación que privilegia lo técnico y simulado sobre lo natural y lo verdadero.

Sin embargo, Borges titula su segundo libro de cuentos con esta palabra, «Artificios», publicado el mismo año que su otro gran libro de cuentos, Ficciones. Hay algo en el título del libro que fuerza la simple significación del artificio como lo secundario, lo derivado, lo falto de dignidad en sí mismo. Como en el otro caso de «Ficciones», Borges no quiere aclarar algo que es de por sí absurdo aclarar: que se trata de productos de la imaginación que no tienen que ver con lo real. No: quizá Borges ya nos alerta de que lo ficcional y lo artificioso, lejos de simular u ocultar, revelan y desocultan. Quizá quiera decirnos que la verdad del hombre y del mundo sean solo accesibles por medio del artificio y de la ficción, y no a pesar de ellos. No por nada, por otra parte, la literatura de Borges ha llamado tanto la atención de los filósofos ${ }^{3}$. «Funes, el memorioso» es, pues, una metáfora. Para el autor argentino, la importancia de la metáfora estriba en hacer patente las «afinidades íntimas», «las secretas simpatías de los conceptos» ${ }^{4}$.

3 Creo que no es necesario insistir en el núcleo filosófico de la narrativa de Borges. Me resulta interesante, sin embargo, una expresión de Wright, quien afirma que muchos de los cuentos de Borges pueden verse como «examples of allegorical hyperbole or hyperbolical allegory, based on paradoxes that inhabit our apparently non-paradoxical world» (WRIGHT, Edmond (2007). «Jorge Luis Borges' "Funes the Memorious”. A philosophical Narrative». Partial Answers. Journal of Literature and the History of Ideas, 5/1: 35). A su vez, subrayando la potencia filosófica de la literatura de Borges, Stewart afirma: «Borges' procedure is to use a particular philosophical doctrine as a point of departure and then to create a world based on it. Then in the course of the cuento, he examines the problems or contradictions which arise in such a world. Thus, he gives in the form of a short story what can be seen as a sort of reduction ad absurdum argument against a given philosophical position. The story allows him to bring out the consequences of a given position and to illustrate them with a character or situation in a way that a philosophical treatise can only do imperfectly with limited examples» (STEWART, J. (1996), «Borges' refutation of nominalism in Funes el memorioso», Variaciones Borges, 2: 69).

4 Borges, J. L., "Historia de la eternidad (1936)», en: Obras completas. Buenos Aires: Emecé, t. I, pp. 455-458. Para un estudio pormenorizado acerca de la metáfora en Borges, cf.: Blanco, M. (2009), «Borges y la metáfora», Variaciones Borges, 9: 5-39. 
Así, las ficciones o artificios, como productos metafóricos, no serían sino modos de escribir y advertir las secretas conexiones entre los fenómenos de la realidad, conexiones que solo pueden establecerse gracias a la palabra y la escritura. Sueño-muerte, vida-ensueño, río-vida —entre otras—, son metáforas constantes en la historia de la literatura, que revelan la realidad solo en tanto que se distancian de ella, solo en tanto que construyen artificiosamente la analogía, inexistente en las cosas mismas. La metáfora es el modo de llevar hacia otro lugar, el modo de trasladarnos al claro donde la verdad de un fenómeno puede revelarse, arrancándolo de la selva pragmática del lenguaje ordinario. Pero, para lograr una metáfora efectiva es preciso una puesta en escena sugerente, por lo cual el artificio de la metáfora, lejos de pecar por abundancia de técnica, peca por su falta. Borges cita a Benedetto Croce y explicita esta imbricación entre verdad y artificio, suspendiendo el prejuicio epistemológico de que la ficción no es verdadera, o es verdadero en un sentido derivado: el filósofo italiano acusaba de «poco ingeniosa ingeniosidad» a los poetas y oradores barrocos del siglo XVII, que no sabían construir metáforas significativas. Es preciso una gran dosis de ingenio para alcanzar la significación y el sentido, para abrir el horizonte de lo verdadero, para despertar estas secretas resonancias de los fenómenos que se hacen patente en el lenguaje. Parece ser que solo en el artificio encontraremos la verdad.

En Borges, empero, parece prevalecer todavía la afirmación de la sujeción de la metáfora a la realidad, rindiendo pleitesía al régimen de la cosa. Ante todo, la metáfora expresa esa resonancia simpática en la que las cosas se conectan entre sí y vibran juntas, tejiendo la trama universal. Como expresión, entonces, se acerca asintóticamente a lo que las cosas son, sin poder nunca alcanzar la verdad de la cosa. El lenguaje, siendo él mismo un artificio que refiere al mundo, deja entrever un meta-lenguaje, un orden racional que pretende ser un «lenguaje» eterno y originario, un orden arque-típico (es decir, de la escritura originaria). Fuera del juego erístico de la metáfora (que nos lleva hacia otra parte), los arquetipos dicen el mundo, y el nombre no es sino el arquetipo de la $\cos a$, su fundamento. Sin embargo, mal que nos pese, el lenguaje humano no es arquetípico, aunque quiera serlo, aunque participe de su carácter originario y creativo. El drama cabalístico del Golem es la muestra de las consecuencias nefastas de un hombre-Dios que profana lo sagrado del lenguaje al tomarlo como una pura técnica de producción, profanación que llega a su apoteosis en la ambición de producir lo vivo ${ }^{5}$. Solo en lo eterno viven los arquetipos, y el lenguaje sigue siendo humano en tanto que habite lo fugaz del tiempo. Lo que Platón remite a lo mítico y místico, en una relación ambivalente respecto a las

\footnotetext{
5 Borges articula la leyenda cabalística con la filosofía de Platón en su poema, «El Golem». Resulta interesante aquí recalcar esta ambivalencia sagrada-profana del lenguaje, en este juego mimético entre un Lenguaje Absoluto y un lenguaje contingente, que recorre mucha de nuestra historia humana. Esta (des)conexión entre ambos planos del lenguaje puede verse con claridad en su conexión con la magia y el encantamiento. Como todavía se patentiza en el idioma inglés, spell significa a la vez «decir, deletrear», y «encantamiento o hechizo».
} 
posibilidades de verdad de lo poético, Spinoza lo encara prometeicamente, en la confianza de una razón que puede llegar a la pureza de una contemplación sub specie aeternitatis. Así expresa Borges su fascinación por este místico de la razón: «Libre de la metáfora y del mito / labra un arduo cristal: el infinito / mapa de Aquel que es todas Sus estrellas ${ }^{6}$. Sin embargo, a pesar de esta pretensión de transparencia óptica, aunque Borges pareciera desestimar la metáfora y el mito por su falta de verdad, el artificio sigue apareciendo en el centro de la escena contemplativa: Spinoza labra un arduo cristal, un infinito mapa. Entramos, pues, en una zona de indiscernibilidad entre el nominalismo y el realismo idealista, en tanto que las razones por desestimar al lenguaje por su artificiosidad e ineficacia de aprehender lo real (corazón que vivifica al nominalismo) parece fundarse en el anhelo humano por decir lo verdadero, sin ningún residuo (pulmón de las respiraciones idealistas) ${ }^{7}$.

6 Borges, J. L. (2007), «Spinoza», en: Obras Completas. Buenos Aires: Emecé, t. II, p. 356. Respecto a la relación entre la literatura de Borges y la filosofía de Spinoza hay una ingente bibliografía. Remito tan solo a algunos estudios: TATIÁN, D. (2017), "Geometría y amistad. Borges, lector de Spinoza», en: Variaciones Borges, 44: 155-172; Paoli, R. (1986), "Borges y Schopenhauer», en: Revista de Crítica Literaria Latinoamericana, 12/24: 173-208; Li, C (2016). «Schopenhauer's fictions», en: Variaciones Borges, 41: 115-127; Almeida, J. (2009), «Borges en clave de Spinoza», en: Variaciones Borges, 9: 163-176.

7 «Borges posee o, mejor dicho, hace uso de una imagen cabalística del mundo, una metáfora maestra de la existencia, con la que es posible que se haya familiarizado ya en 1914, en Ginebra, al leer la novela El Golem de Gustav Meyrink y a través de sus contactos íntimos con el erudito Maurice Abramowicz. La metáfora es más o menos la siguiente: el Universo es un gran Libro; todos los fenómenos materiales y mentales de ese libro tienen significado. El mundo es un inmenso alfabeto. La realidad física, los hechos de la historia, todas las cosas que han creado los hombres, son, por así decirlo, sílabas de un mensaje perpetuo» (George Steiner, citado en: Mitr, R. (2006), «Borges y el acto poético», Metapolítica, 47, p. 52). Creo que en esta metáfora del mundo como lenguaje se juega la ambivalencia filosófica de Borges que, por un lado, anhela la pretensión de un lenguaje que coincida con la cosa, y, por otro lado, desestima la propiedad del lenguaje como tal. El problema con la metáfora lingüística es que, al mismo tiempo, remite a un plano humano y a un plano divino: todo depende de quién sea (A)aquel que hable. Esta ambivalencia en la obra de Borges es rescatada como tal por Boulter: «I suggested at the outset of this analysis that I would attempt to find a middle ground between the vision of Borges as metaphysician, with his grounding belief in systems of order, and the vision of Borges as postmodern master celebrating textuality in excess of any ground. My solution to the problem is the idea that Borges' figuration of the simulacrum celebrates and critiques simultaneously both positions: "la ambigüedad es una riqueza", as he reminds us in "Menard". This position is not one assumed for reasons of a relativized vision of things. Borges' suggestion is that human language (and intellect) can only approximate the infinite through a process of dialectics, a process that offers a partial glimpse of totality undermined by an awareness of the partiality of that glimpse. The complexity of Borges' vision lies precisely in its awareness of its partiality, a partiality that dictates that both positions - the vision of totality and its undermining - must be maintained in a rigorous system of dialectical complementarity. The temptation to read this complementary polysemy as sure evidence of Borges' postmodernity must finally ignore that a simultaneous plurality of theoretical positions makes impossible, but gloriously so, any fundamental theoretical categorization of the effects of his stories: a plurality of simultaneous positions, like an Aleph 
Sabemos la tensión que estos dos elementos, el cristal/espejo y el mapa, despiertan en la literatura de Borges. Respecto del segundo, la pretensión de una rigurosidad en la que la palabra alcance la cosa, como si el lenguaje calcara los contornos de lo real, termina en la peor de las vanidades: un mapa infinito, que llegara a una precisión tal que se identificara con el territorio, dejaría de ser mapa, y no sería sino su inútil duplicación sin diferencia. El mapa, si se quiere, es una extensión técnica de nuestra capacidad de ubicarnos en el contexto de un espacio que me excede indefinidamente, pero en el cual debo moverme y vivir. Como la metáfora, el mapa es el modo en que podemos enfrentar y abordar el territorio, de por sí hostil, de por sí inhumano, de por sí inasible e inabordable. Solo se habita en el mapa. Una pura rigurosidad científica, gracias a la cual el mapa se identifica con el territorio, suspendería el sentido mismo de mapa, y tornaría la ciencia inhumana, insignificante, porque el saber y el conocimiento son una expresión de nuestra vitalidad, de nuestro ser-en-el-mundo y, por tanto, un órgano de nuestra orientación.

En el caso de los espejos o cristales ${ }^{8}$, el «arduo cristal» que Spinoza labra, es aquél que consigue, al mismo tiempo, la precisión de un mapa infinito en su poder de observación (al modo de un telescopio-microscopio, que aprehende, al mismo tiempo, lo mínimo y lo máximo, los dos infinitos pascalianos), y el que refleja - como el mapa que coincide con el territorio- el Arcano del mundo, que no es sino Dios, «Aquel que es todas sus Estrellas». Recordemos que, para Spinoza, Dios es la sustancia única que se identifica con el mundo: Deus sive Natura. Aquí se desata sin control y frenéticamente el infinito juego óptico de la visión, de los reflejos y de los espejos: Dios es, Él mismo, el mapa único que se identifica con su territorio, la razón que se identifica con la cosa, Dios o Naturaleza, porque se ve a sí mismo ver, en la visión de sí, que es la visión del todo, porque el Todo es Él mismo, es Sí mismo, etcétera. Este Dios es razón suma, una razón que piensa lo real sin resto. Sin embargo, en tanto que razón, en tanto que operación refleja y reflexiva, Dios ya está referido a otro que sí, aún cuando en esta reflexión sin resto la diferencia quede asimilada hasta la indistinción respecto de sí. El primer cristal, el espejo absoluto e infinito, es

— simulated or not- is at once totalizing and relative, is radically but rigorously dialectical» (Boulter, J. S (2001), «Partial Glimpses of the Infinite: Borges and the Simulacrum», en: Hispanic Review, 69/3: pp. 374-375). El autor examina hasta qué punto la ontología borgeana no encaja completamente en la caracterización de la postmodernidad a partir de los órdenes de simulación propuesto por Jean Baudrillard, donde el último orden de los simulacra se identifica con la simulación como lo real. Así, no se puede simplemente encajar a Borges en una u otra postura, sino que, como artista más que como filósofo, el maestro argentino muestra ficcionalmente las grietas y los quiebres de cualquier reflexión sobre lo absoluto. Todo nuestro ensayo girará en torno a estas paradojas y tensiones dialécticas a partir, sobre todo, del caso «Funes».

8 En este caso, el cristal al que refiere Borges da cuenta tanto de la característica amplificatoria de los cristales, como en los anteojos y telescopios, como a su característica reflectiva. Si no usa «espejos», tópico más netamente borgeano, es por las necesidades biográficas de Spinoza, quien trabajaba en una óptica. 
Dios mismo, y es a este Dios a quien queremos parecernos, es a esta deificación intelectualista a la que apunta la filosofía. No obstante, la razón humana tan solo puede imitar esta reflexividad en un intento desesperado por anular el resto, por suspender la trascendencia sin reflejo de lo real. La razón humana es imagen de la razón divina, su pálido reflejo, y alcanza su esencial vocación de absoluto en tanto que contempla desde la eternidad, en tanto que participa de la visión de Dios, cuya operación es, a su vez, su objeto (en la estela del Dios aristotélico que es pensamiento de pensamiento).

\section{LA DUPLICACIÓN Y EL RESTO}

La metáfora se encuentra en el corazón de nuestra experiencia, en el núcleo intraspasable en el que nuestras vivencias tienen sentido. Las ficciones y artificios siguen siendo la única manera de enfrentar lo real y lo verdadero, y lejos de velar y esconder, son las únicas capaces de revelar y producir significado, las únicas que hacen posible un habitar humano en el mundo. La ficción y el artificio, pues, son solo significativas si dejan un resto, es decir, si abandonan su pretensión de presentar lo que re-presentan. Sin embargo, el anhelo profundo de nuestro lenguaje es conquistar la cosa, decirla completamente, re-presentarla sin veladuras, duplicarla sin dobleces, planchada, sin pliegues.

En la literatura de Borges esta dramática situación del hombre, que busca vanidosamente representar sin resto al original, es un tópico central. Trasladando el problema de la duplicación al caso de arte, el escritor argentino pone en cuestión el lugar mismo del autor y de la obra, del acto creativo y del cauce de la tradición. En «Pierre Menard, autor del Quijote», lo que interesa al narrador - y amigo del personaje Pierre Menard - es recuperar su obra invisible, «la subterránea, la interminablemente heroica, la impar»9. Tal obra, «quizá la más significativa de nuestro tiempo», consta de los capítulos IX y XXXVIII de la primera parte del Don Quijote y de un fragmento del capítulo XXII. Peca de ingenuo quien viera en el intento de Menard una mera repetición del Quijote, o una mera copia. Se trata de escribir lo mismo, pero diferente: se trata de alterar la obra, alterando el autor, aunque la obra parezca ser la misma. Llegar al Quijote desde Menard era, para el narrador, enriquecer infinitamente la obra de Cervantes. «El texto de Cervantes y de Menard son verbalmente idénticos, pero el segundo es casi infinitamente más rico» ${ }^{10}$. Así, observaba Pierre Menard que su proyecto era harto más difícil que el de Cervantes:

«Mi complaciente precursor no rehusó la colaboración del azar: iba componiendo la obra inmortal un poco a la diable, llevado por inercias del

9 Borges, J. L. (2007), «Pierre Menard, autor del Quijote», en: Obras completas. Buenos Aires: Emecé, t. I, p. 532.

10 «Pierre Menard, autor del Quijote», p. 536 [cuando no se cite el autor, se tratará siempre de obras de Borges]. 
lenguaje y de la invención. Yo he contraído el misterioso deber de reconstruir literalmente su obra espontánea. Mi solitario juego está gobernado por dos leyes polares. La primera me permite ensayar variantes de tipo formal o psicológico; la segunda me obliga a sacrificarlas al texto "original" y a razonar de un modo irrefutable esa aniquilación. A esas trabas artificiales hay que sumar otra, congénita. Componer el Quijote a principios del siglo XVII era una empresa razonable, necesaria, acaso fatal; a principios del siglo $\mathrm{XX}$, es casi imposible. No en vano han transcurrido trescientos años, cargados de complejísimos hechos. Entre ellos, para mencionar uno solo: el mismo Quijote» ${ }^{11}$.

El método de Menard parece apropiarse de la obra del Quijote de modo definitivo, pasando por los procesos inconscientes de la escritura y haciéndolos conscientes, para sacrificarlos luego al «original». Es una reconstrucción de la obra que coincide finalmente con su construcción, forzando hasta el límite las posibilidades artificiosas de dicha labor, en el que el artificio parece buscar suspender lo que lo hace ser artificio, es decir, suspender la diferencia misma entre duplicación y original. Pero esta coincidencia solo puede ser fundamentada en la indistinción del autor, o mejor, en la aniquilación del autor por parte del lenguaje o de la tradición. ¿Quién escribe el Quijote, pues, Cervantes o la tradición o el lenguaje que se apodera de él? Como en el Doktor Faustus, de Thomas Mann, el artista es un poseído, alguien que produce sin ningún tipo de control sobre su obra, como si su obra no le perteneciese, en rigor, sino que le pertenece al fatal destino de una revelación histórico-lingüística (no es azaroso que el narrador rescate del Quijote y de su reescritura de Menard el pasaje en el que se afirma que "la historia es la madre de la verdad»). "A pesar de estos tres obstáculos —afirma el narrador-, el fragmentario Quijote de Menard es más sutil que el de Cervantes» ${ }^{12}$. Es más sutil porque intenta apoderarse de este inapropiable lenguaje que todo lo constituye, aunque dicho intento sea absolutamente vano y fútil: la sutilidad de Menard obedece al reconocimiento de esta vanidad, a la exploración metódica y a la impúdica publicación de los mecanismos del lenguaje que constituyen un discurso y una obra desde sí mismos, fatalmente ${ }^{13}$. Y Menard lo hace con una dilación infinita, una dilación que solo podría finalizarse en una vida inmortal ${ }^{14}$, sin diferir tampoco su presentación

11 «Pierre Menard, autor del Quijote», p. 535, subrayado mío.

12 «Pierre Menard, autor del Quijote», p: 536.

13 «No hay ejercicio intelectual que no sea finalmente inútil. Una doctrina filosófica es al principio una descripción verosímil del universo; giran los años y es un mero capítulo — cuando no un párrafo o un nombre - de la historia de la filosofía. En la literatura, esa caducidad final es aún más notoria. "El Quijote" me dijo Menard "fue ante todo un libro agradable; ahora es una ocasión de brindis patrióticos, de soberbia gramatical, de obscenas ediciones de lujo. La gloria es una incomprensión y quizá la peor". Nada tienen de nuevo esas comprobaciones nihilistas; lo singular es la decisión que de ellas derivó Pierre Menard. Resolvió adelantarse a la vanidad que aguarda todas las fatigas del hombre; acometió una empresa complejísima y de antemano fútil. Dedicó sus escrúpulos y vigilias a repetir en un idioma ajeno un libro preexistente» («Pierre Menard, autor del Quijote», p. 537).

14 «Me bastaría ser inmortal para llevarla a cabo», le dice Menard al narrador («Pierre Menard, autor del Quijote», p. 534). 
definitiva publicando sus estadios intermedios, en una especie de absurdo sueño heroico (propio de un Quijote) por lograr lo imposible ${ }^{15}$.

El ejercicio intelectual y artístico de Menard mina las bases mismas del arte y de la autoridad, desdibujando las diferencias entre copia y original, entre autor y lector, entre creación y tradición, y todo ello lo logra al suspender la operación semántica del «como si», o, mejor, llevando esta operación hasta su punto culminante, es decir, hasta el punto en el que el «como si» ya deja de ser ficcional y se indetermina hasta la confusión con lo real. Pero aún este ejercicio tampoco puede ser atribuido a su autor, como si se desligara de la moira del lenguaje. Lo que se cuestiona aquí no es sino la pretensión de transparencia e inmediación del sujeto sobre sí mismo, el control voluntario de sus operaciones, la soberanía sobre su lenguaje y pensamiento. «Menard (acaso sin quererlo) ha enriquecido mediante una técnica nueva el arte detenido y rudimentario de la lectura: la técnica del anacronismo deliberado y de las atribuciones erróneas» ${ }^{16}$. Leer lo anterior (Odisea) como lo posterior (Eneida), o leer un libro de un autor (Bachelier) como perteneciente a ese autor (Bachelier), son operaciones idénticas: el «como si» no guarda ya el umbral entre lo verdadero y lo falso, entre el original y la copia. La suspensión del «como si» en su absoluta realización termina por llevar a la indecidibilidad toda decisión/escisión entre los opuestos: la re-construcción del Quijote de Menard no es más que la expresión última de la de-construcción del Quijote. "¿Confesaré que suelo imaginar que la terminó [su obra] y que leo el Quijote - todo el Quijote-como si lo hubiera pensado Menard? ${ }^{17}$ Destino criminal de todo signo, que asesina a lo significado en su representar sin resto, en su vocación última de superar el abismo que lo separa de su referente. En el «como si» de la representación, del signo, asecha la sustitución última, la aniquilación de lo real —y, por tanto, también de lo ficcional: si ya todo es signo, entonces ya nada es signo ${ }^{18}$.

15 «"Mi propósito es meramente asombroso", me escribió el 30 de septiembre de 1934 desde Bayonne. "El término final de una demostración teológica o metafísica —el mundo externo, Dios, la casualidad, las formas universales- no es menos anterior y común que mi divulgada novela. La sola diferencia es que los filósofos publican en agradables volúmenes las etapas intermediarias de su labor y que yo he resuelto perderlas". En efecto, no queda un solo borrador que atestigüe ese trabajo de años» («Pierre Menard, autor del Quijote»: pp. 533-534).

16 «Pierre Menard, autor del Quijote», p. 538, subrayado mío.

17 «Pierre Menard, autor del Quijote», p. 534, subrayado mío.

18 Para Barrenechea, pareciera que el lenguaje para Borges es un instrumento de perdición y de engaño, dado su carácter mediador y la falsedad de los términos que pretenden asir la realidad concreta en el sentido universal de la palabra. Si bien este recelo es cierto, y puede encontrarse en la obra de Borges, no es menos cierto señalar que es, justamente, el carácter mediador del lenguaje lo que lo hace único, lo que lo hace ser el verdadero portal para entrar al universo: sin palabras, no hay pensamiento, no hay percepción, no hay cosas. «Las lenguas son, en último término, simplificaciones de una realidad que siempre las rebasa, y solo pueden justificarse con un fin práctico. Son sobre todo esencialmente inaptas para expresar la riqueza y la originalidad de las intuiciones poéticas. Borges siente como escritor que las experiencias son inefables porque es inútil querer traducir con palabras comunes a 


\section{InVertir (EN) El Absoluto}

¿Por qué todos estos rodeos? ¿Qué tienen en común el problema de las duplicaciones con el cuento que nos convoca, que gira en torno a la memoria y al olvido? ¿Cuál su relación con el insomnio, cuya metáfora quiere ser Funes? La idea que atraviesa esta narración, y la marida misteriosamente con los otros textos considerados es, creo, la idea de escisión, la idea de corte, de tajo, de interrupción. La tesis que parece hilvanar estos textos es que el hombre es, ante todo, un vidente con párpados, un vigilante que duerme, un individuo que difiere en el tiempo, un sapiente al que le está vedado el total conocimiento, un sintiente al que se le niega la percepción ininterrumpida de lo real. Si Ireneo es una metáfora del insomnio, es porque Funes es una metáfora de la muerte, o mejor, de la incapacidad de morir, de la incapacidad de cerrar los ojos ${ }^{19}$. Si la

todos lo único de cada individuo y de cada circunstancia» (BARRENECHEA, A. M. (1957), La expresión de la irrealidad en la obra de Jorge Luis Borges, México: El Colegio de México, p. 78). Sin embargo, como veremos en «Funes», la misma debilidad del lenguaje es su fuerte, ya que no hay intuición inmediata de la realidad, es decir, que solo hay intuición por medio de la palabra, y solo gracias a ellas es que podemos hablar de realidad y de su desborde: el silencio solo es significativo porque hay palabra, y es insignificante si es tan solo la falta de sonido. Así también lo señala Barrenechea: «Aunque en general predomine en su obra la visión negativa del lenguaje, no deja de reconocer que no sería posible el pensamiento sin la simplificación que las ideas imponen. Así vemos que sabe gozar artísticamente con un cosmos que se abarca porque se ha esquematizado y ordenado. Junto a la nostalgia que inspira una memoria que pierde detalles "irrecuperables", exalta la memoria y la noche que solo conservan lo esencial de las cosas. (...) Frente a los arquetipos platónicos, fríos y monstruosos como piezas de museo, siente los arquetipos que purifican y eternizan aun a costa del empobrecimiento. Por eso también puede valorar estéticamente los símbolos que las matemáticas y la geometría le proporcionan con su límpida manera de traducir el misterio inexplicable». Ibid., pp. 81-82).

19 Analizando las fuentes idealistas de Borges, Samuel Moder escribe: «En este sentido, podríamos afirmar que "Del rigor en la ciencia" explota la paradoja que se produce cuando, tras haber anulado toda diferencia con su objeto, la búsqueda de absoluta exactitud en una representación conduce al hallazgo de una identidad perfecta. Pensemos, por ejemplo, en las filosofías idealistas que tanto interesan a Borges. Sin intentar reducir éstas a una simple fórmula - lejos de negar la multiplicidad de sus matices y la sofisticación de sus argumentos-, podríamos decir que cualquier buen candidato al idealismo afirmará sin pestañear que el conocimiento es posible solo a condición de que la conciencia represente en forma exacta la realidad» (Monder, S. (2009), «Del rigor del lenguaje: Borges y las cartografías de lo Real». Variaciones Borges, 27, p. 102, subrayado nuestro). Inconscientemente, quizá, el autor utiliza el verbo "pestañear» en el contexto de la inmediación y de la pura identidad entre la representación y el objeto. En realidad, lo que genera la diferencia entre representación y objeto es la suspensión de la presencia, el hecho de la inter-rupción, el hecho de que lo real irrumpe al tiempo que irrumpe el sujeto, interrumpiéndose mutuamente, quebrando la supuesta presencia de sí a sí, la supuesta solidez de lo «en sí» o de lo "para sí». No por nada, el idealismo alude a la eternidad como el elemento en el que se da la visión (inmediata) de lo Real. Monder afirma que «la exactitud es la pasión básica de Ireneo Funes», e interpreta el personaje de Funes a partir de su actividad de trenzador, siendo el trenzar una metáfora del hablar. «Lo que deseo sugerir, en todo caso, es que "Funes, el memorioso" es un relato sobre el lenguaje; y si bien su planteo involucra una dimensión temporal que tiene que ver con la 
simpatía semántica entre el sueño y la muerte es uno de los grandes tópicos de la literatura, uno de esos arquetipos que no dejan de aparecer en la historia con una fuerza arcana, entonces el insomnio podría conectarse con la idea de vida. Una pura vida sería aquella donde no se duerme, donde no se sueña, donde no hay corte alguno. Es la idea teológica de una vida eterna en presencia de lo Absoluto, la idea de una vissio beatifica. Frente a Dios, los bienaventurados no duermen; los salvos se regocijan eternamente de una visión eterna, dotados de unos ojos sin párpados; de unos ojos sin cabeza ni pies tampoco, unos ojos que no conocen perspectiva porque todo lo ven. Unos ojos, por tanto, que no olvidan, porque no conocen pasado ni futuro, sino solo presente; unos ojos que recuerdan sin resto, una memoria sin cesura, una memoria que ya no merece tal nombre porque entre lo re-presentado y la presentación no hay sino identidad, in-diferencia. Una vida beata, digna de los dioses, y en la que participamos como invitados de honor, es una vida en presente, una vida que es toda ella presente. Como ya nos enseñaba Boecio en el siglo $\mathrm{V}$, la eternidad no es una

memoria, las consecuencias de éste afectan la totalidad de nuestra percepción y la formación de ideas generales» (Monder, S., «Del rigor del lenguaje: Borges y las cartografías de lo Real», p. 104). «El lenguaje, sistema de diferencias, funciona con la pérdida de lo real, en su contaminación de ausencia. Confrontado con lo opuesto, Funes avanza hacia la pérdida del lenguaje. (...) La pérdida del lenguaje es, a fin de cuentas, pérdida de la realidad; no entrada en la referencia, sino ausencia de referencia» (Alberto Moreiras, citado en Monder, S.,. «Del rigor del lenguaje: Borges y las cartografías de lo Real», p. 105, n. 7). Así, Monder argumenta que es preciso un espacio donde sea posible rescatar la contingencia del lenguaje, en tanto que la palabra es siempre una metáfora que intenta representar una realidad, pero que ninguna metáfora puede ser tenida como superior a otra. Frente a la filosofía, «quizá la literatura de ficción ofrezca ese espacio» («Del rigor del lenguaje: Borges y las cartografías de lo Real», p. 113). Porque la filosofía no puede hacerse cargo de la materialidad de su lenguaje. «En efecto, el sueño de la filosofía es el sueño de un lenguaje necesario, no contingente, entendido como aquel cuyos cortes conceptuales (el trenzador, nuevamente) coinciden con las articulaciones mismas del Ser: las distinciones que trazaría este lenguaje no tendrían ya que ver con los caprichos del hombre, sino con la Forma misma del Universo» («Del rigor del lenguaje: Borges y las cartografías de lo Real», p. 109). Claro que el problema con Borges es su ambigüedad respecto al estatuto del lenguaje, por lo cual ha sido leído tanto como nominalista como antinominalista (Cf. MARTín, J. (2010), «Borges, ¿nominalista o antinominalista?», en: Variaciones Borges, 30: pp. 183-197), lo cual es también paralelo a que fue leído tanto como pragmatista y como idealista (Peters, J. (2008), «Resemblance made Absolutely Exact: Borges and Royce on Maps», en: Variaciones Borges, 25: pp. 1-24.), o si se quiere como aristotélico y como platónico. Para Jorge Martin, Borges no es ni uno ni otro sino que, haciendo una lectura paralela de la filosofía de Henri Bergson concluye: «Dejando de lado los casos límites, Borges tiene en cuenta también las posturas intermedias, con sus orientaciones moderadamente nominalista y conceptualista. Como hemos visto, él admite que son dos formas de acceso a la realidad, porque en el fondo dependen de diversos grados de tensión psicológica. Por eso, no se puede decir que el escritor sea nominalista o antinominalista en forma exclusiva: es al mismo tiempo las dos cosas (porque toda mente humana normal lo es en diferentes proporciones), pero se entretiene literariamente refutando a las visiones unilaterales que simplifican groseramente el arduo problema de las ideas generales» (MARTín, J., (2010), «Borges, ¿nominalista o antinominalista?», p. 197). 
vida interminable, sino una vida en la que todo es presente. Lo divino es, por ello, presencia de sí ante sí.

Pero pasemos a la lectura de «Funes, el memorioso». "Lo recuerdo (yo no tengo derecho a pronunciar ese verbo sagrado, sólo un hombre en la tierra tuvo derecho y ese hombre ha muerto) con una oscura pasionaria en la mano, viéndola como nadie la ha visto, aunque la mirara desde el crepúsculo del día hasta el de la noche, una vida entera ${ }^{20}$. Así comienza «Funes»; así comienza nuestra meditación de lo funesto. Recordar es un verbo sagrado, un verbo que conecta lo humano con lo divino, a través de la idea de visión (la idea es, ya lo sabemos, visión, es lo visto, según su etimología griega), un verbo que solo un hombre muerto ya - ha podido pronunciar y actuar sin escándalo, un hombre que nos escandaliza tanto como ese Cristo que clamaba ser Dios. Lo que hace de este hombre alguien único, atravesado por el rayo de lo divino hasta su perdición, es su capacidad de visión, una visión cuya intensidad no puede medirse por las categorías cuantitativas aplicadas al tiempo (no importa cuánto tiempo miráramos un objeto: ni siquiera si la viéramos una vida entera alcanzaríamos la visión que tenía Funes de las cosas), sino tan solo proclamarse, pronunciarse, por la fuerza de su cualidad. Una vida entera no alcanza la visión de Funes, porque lo entero de una vida es el tiempo que discurre entre su principio y su fin. Como en el caso de los dioses, y de los felices que participan de la vida divina («felicidad», en griego, se dice estar poseído por un buen dios, eu-daimonía), la visión de este hombre -muerto ya- es ab-soluta, sin diferencia, sin dilación; una visión eterna, en una palabra. Y, sin embargo (sin embargo, es decir, sin destitución, sin resto), este hombre-Dios, este presunto bienaventurado, corre la misma suerte que el personaje cuya novela no abandona sus manos, ese otro (¿único también?) hombre-Dios cuyo destino ha sido la pasión, el abandono de Dios en la Cruz. En el artificio de la literatura, el hombre cuya visión es plena encuentra su drama en ese otro hombre, también divino, que suda sangre en el jardín de los olivos. Los hombres-Dios, parece, difícilmente pueden llamarse bienaventurados, al menos si nos fijamos en aquellos que habitaron en Jerusalén o en Fray Bentos. El entusiasmado (otra palabra griega para decir poseído) es un condenado, allí donde lo divino aplasta lo humano, allí donde lo humano no sobrevive a su divinización. Y es que, tal vez, un hombre así no puede ser hombre, ni Dios. Y es que, tal vez, este otro hombre-Dios no sea realmente divino ni humano, porque lo humano no puede divinizarse sino en su carácter propiamente humano, es decir, en lo que lo separa de lo divino, en su pecado, en su falta: quizá el hombre-Dios no sea, en última instancia, ese Cristo que muere en cruz, sino aquél que entrega con un beso al más santo de los hombres. Quizá el hombre-Dios no sea más que una bestia ${ }^{21}$.

20 Borges, J. L. (2007), «Funes, el memorioso», en: Obras completes. Buenos Aires: Emecé, t. I, p. 585.

21 «Funes, despite his infinite knowledge of particulars, is constantly associated with the darkness of ignorance. He is not liberated by his superhuman capacities, but on the contrary they render him a prisoner»: STEWART, J. (1996), «Borges' refutation of nominalism in Funes el memorioso», p. 85. 
En todo caso, la primera palabra del cuento no es el verbo, sino el pronombre clítico que denomina en ausencia el objeto de dicho verbo: «lo». «Lo recuerdo», afirma en el principio el narrador. Y es que no puede ser de otra manera: recordar es grabar, es mantener lo percibido presente, aún en su ausencia. El narrador no puede recordar sin recortar: lo recuerdo significa que, dentro de la totalidad de la visión, el narrador parpadea, escinde su vivencia para pro-ducir sus objetos, para llevar delante de sí lo que considera. El objeto del recuerdo es lo que se recuerda. Siguiendo el mandamiento de la fenomenología, no se piensa ni se recuerda sino intencionando un objeto, con-figurando una vivencia y tornándola fenómeno. No recuerdo sino recordando algo, recordando-lo. Un recuerdo ab-soluto, des-atado, sin su complemento objetivo, sería un recuerdo cuya visión no conoce escisión ni corte, una visión completamente idéntica a la vivencia, una visión sin ob-jeto, sin nada en frente, o frente al todo en cuanto todo. Un recordar sin recortar es un recuerdo que se anula como recuerdo. El narrador recuerda, recorta. Recuerda, siempre en primera persona, la cara taciturna y distante, remota, detrás del cigarrillo; recuerda (al menos cree recordar) las manos trenzadoras, y el mate a su lado; recuerda la ventana de la habitación; recuerda claramente, la voz del condenado-bienaventurado hombre-Dios. Lo recuerda en la pluralidad de sus perspectivas, en la sumatoria de sus escorzos que revelan un todo de por sí inaccesible. Y es que recordar es recortar. Recuerdo (recorto) las manos, la voz, el mate, la esterilla en la ventana. Lo recuerdo no es más que la síntesis de todas esas percepciones, siempre parciales, de aquello que figura sobre el fondo de la experiencia. He aquí sus manos, allí su voz, y entre ellas, él, ecce homo, aquel «precursor de los superhombres» (según el epíteto que otro de los biógrafos de Ireneo Funes ofrece).

Lo sagrado del verbo recordar no puede sino profanarse en su transitividad, en su necesidad de un objeto, en la convocatoria de su complemento. Y el narrador del cuento no hace sino profanar, una y otra vez, ese verbo: lo recuerdo, recuerdo tal y cual cosa.... Difícil es contar las veces que el narrador utiliza este verbo - y su obligado complemento objetivo. Un recuerdo que, dicho sea de paso, se construye, se teje, se escribe, con el auxilio de otros narradores: «me dijo que el muchacho del callejón era un tal Ireneo Funes». Ese auxilio preciso de los otros, en este caso, del primo del narrador, sin el cual su encuentro con Funes hubiera pasado des-apercibido; ese auxilio que lo lleva al narrador a detenerse en la vivencia, a cerrar sus ojos para grabar la experiencia; esa vivencia que hubiera estado condenada a la pérdida "si no lo hubiera recalcado mi primo». Y es que re-cordar es re-calcar, es trazar el mapa sobre el territorio de la vivencia, para salvarlo, para arrancarlo del flujo y la corriente incansable de la experiencia, para poder orientarnos y habitar en el tiempo.

Recordar es también un arte, una técnica, un artificio, una herramienta gracias a la cual lo percibido queda a flote en este río heraclíteo de la conciencia. El recuerdo es la amarra, el ancla de lo vivido, aquello que fija el flujo, que detiene lo que corre; una especie de inmovilización de lo que no conoce descanso. En una especie de taxidermia de la experiencia, el recuerdo destripa la vivencia y la representa en su cadáver, la presenta en su epidermis, en esa piel sin 
sustancia, en ese pecho que no late; ese orden de la piel sin carne (taxi-dermia). Se trata de un artificio, de la producción de la ilusión: allí donde lo vivo muere - pero vive en su espectro. Juego de espejos y reflejos. Juego de cartógrafo sin naves ni océanos. Un artificio que conoce grados de prodigiosidad, según lo refiere Plinio en su Naturalis historia, referido a su vez por Funes y el narrador, referido a su vez por Borges, y que ahora yo refiero y referirán todavía mañana. Un artificio que dominaba Cirio, rey de los persas, cuyos ejércitos eran la colección de todos los nombres de sus elementos; y Mitrídates Eupator, cuyos 22 idiomas administraban su polígloto imperio; y aquél que podía repetir con absoluta fidelidad lo que había escuchado una sola vez, Metrodoro; o Simónides, el inventor de la mnemotecnia. "Mnemo-tecnia», la técnica de la memoria, algo que aún hoy se practica. Pero una técnica que, en rigor, se apoya ya sobre otra técnica, una técnica al segundo grado, podríamos decir. Una especie de instrumento superpuesto a un instrumento, como prótesis de otra prótesis. Si el recordar es el acto de la memoria, y el recordar es ya un artificio, un productor de espectros e ilusiones, entonces la mnemotecnia no es sino el arte de dominar dicho instrumento, la técnica de domeñar los fantasmas (pues la memoria es la bóveda de las fantasías, de los productos de la imaginación, de las síntesis perceptivas que se generan en la imaginación). Un artificio al cuadrado, una mejora del artefacto de la memoria. Una mejora ridícula, de todas maneras; una mejora de aquello que es de por sí defectuoso, falible, indigno. Este hombreDios, único que puede pronunciar el verbo sagrado del recordar sin profanarlo, se maravilla de que tales proezas sean objeto de admiración, él, cuya memoria no conoce posibilidad de mejora, él, cuya memoria ya no es artificiosa porque no hay diferencia entre sus recuerdos y la realidad a la que refieren.

En el espectro indiscernible en el que lo vivido y lo recordado no es escindido por frontera alguna, vive este hombre-Dios ${ }^{22}$. En este destino signado ya por su nombre (pues «quien recibe un nombre, recibe un destino», según el verso de Leopoldo Marechal), Ireneo muere en vida. «Funes» es su nombre, no el nombre propio, sino el nombre sin más (ese que el sustantivo español «apellido» no logra alcanzar en su carácter de nombre, como sucede con el latín, el francés, el alemán, donde el nombre verdadero pronuncia la pertenencia de un individuo a un destino que lo trasciende). Ese destino, ciertamente "funesto», que cumplió Ireneo Funes en el momento de su accidente, aquél que lo ha dejado «tullido, sin esperanza», es, sin embargo, el momento en que su humanidad

22 «El empleo de los sueños no escapa a la curiosidad creadora de Borges. (...) No importa cuál sea su medio expresivo, la intención es la misma: especular con la problemática que ofrece la relación del hombre con el mundo; crear, tal vez, otro; buscar en definitiva la trascendencia de lo esencial a través de una dimensión onírica. En su estudio sobre la obra de Borges, la profesora Barrenechea registra los espejos y los sueños como símbolos de irrealidad. Sobre los sueños en particular, la autora ha dicho que "son otra forma de sugerir la indeterminación de los límites entre mundo real y mundo ficticio”. Esta tensión de opuestos, entre mundo real y mundo ficticio, será en Borges el principio generador de la expresión creadora» (ARAngo, G. (1973), «La función del sueño en "Las ruinas circulares” de Jorge Luis Borges», en: Hispania, 56: 249). 
se torna divina. Como todo don inmenso, inconmensurable, Ireneo paga con su humanidad el precio de su theosis; paga con la única moneda que corre en estas transacciones, la sangre. Y, sin embargo, en esta ambivalencia del regalo, del don, del gift, que es a la vez bendición y condena, Funes encuentra regocijo:

«Me dijeron que no se movía del catre, puestos los ojos en la higuera del fondo o en una telaraña. En los atardeceres, permitía que lo sacaran a la ventana. Llevaba la soberbia hasta el punto de simular que era benéfico el golpe que lo había fulminado... Dos veces lo vi atrás de la reja, que burdamente recalcaba su condición de eterno prisionero: una, inmóvil, con los ojos cerrados; otra, inmóvil también, absorto en la contemplación de un oloroso gajo de santonina ${ }^{23}$.

Hasta qué punto era soberbia lo que animaba la pose estoica de Funes, o hasta dónde no era realmente un sentimiento auténtico de dicha. En todo caso, las veces que nuestro narrador vio a Funes lo encontró en la frontera misma entre planos y mundos: frente a la ventana guardada por hierros impermeables, allí donde el afuera y el adentro se encuentran, pero no pueden tocarse. En una especie de prisión, Funes se encuentra inmóvil. Pero, ¿de qué tipo de prisionero se trata, y de qué tipo de inmovilidad hablamos? Lo que parece ser una condena puede, en efecto, ser la suma liberación: Funes es un eterno prisionero, o un prisionero de la eternidad, incapaz de moverse no por defecto, sino por exceso. Así como lo eterno es inmóvil, pero por ello más perfecto que lo que es devorado por el tiempo mudable, así Funes se sostiene con la gloria de los mármoles, aquellos que no conocen fluir alguno. No se mueve porque a lo que se enfrenta es también inmóvil: por una necesidad fenomenológica, el sujeto se configura frente a su objeto y viceversa ${ }^{24}$. Funes contempla, está absorto, se encuentra más allá del río heraclíteo de esta realidad putrefacta, y se enfrenta a sí mismo, a sus propios estados mentales, se enfrenta a sus ideas, aquellas que participan de la dignidad sin mancha de lo arquetípico, de lo uránico. Como una encarnación del ideal griego, Funes es una imagen móvil de aquel Motor inmóvil aristotélico, indiferente e impasible a todo lo que no sea su propia actividad: Funes piensa al pensarse, vive al vivirse, separado,

23 «Funes, el memorioso», subrayado mío.

24 Respecto a la subjetividad de Ireneo Funes, Sánchez y Bellido afirman, pivoteando en el idealismo trascendental de Immanuel Kant, que «solo por referencia a una única conciencia, mi conciencia, puedo realizar síntesis objetivas en la experiencia, y poseer el conocimiento de las mismas bajo la forma de objetos» (SÁnchez, Ayelén; Bellido ARias, Andrés (2013), «Funes, ¿qué Funes?, el memorioso. Un análisis de la subjetividad del personaje de Borges, a partir de conceptos nietzscheanos», en: Coronado-Schwindt, Gastaldi, MarRón \& Rodríguez (eds.), Palimpsestos: Escrituras y Reescrituras de las Culturas Antigua y Medieval. Bahía Blanca: Editorial de la Universidad Nacional del Sur, p. 318). De este modo, las unidades perceptivas son correlatos de una unidad de conciencia. El tipo de unidad subjetiva, en Funes, se destruye al tiempo que la unidad de la percepción se pulveriza; y, sin embargo, el ideal de un sujeto puro ante un objeto único es, también realizado en Funes. Nuevamente, creo que la narrativa de Borges nos pone frente a una absoluta imposibilidad de pensar sin contradicción el paradigma de la inmediación. 
arrancado de la vulnerable condición de lo temporal. Cierra sus ojos porque es ciego, porque ya no los necesita, porque ha alcanzado una visión que está por fuera del marco espacio-temporal, aquella visión que bautizó a fuego la realidad eidética. Ab-sorto, está en lo abstracto, separado de lo concreto, exiliado de la vida en la bienaventuranza ambigua de lo eterno, en aquella felicidad improbable del tullido, de aquel que ya no tiene futuro ni tiempo, de aquél que ya no puede moverse, ni tampoco necesita hacerlo. Destino inexorable de aquel «cronométrico Funes», cuyo dominio de la medición del tiempo ya anunciaba una relación de indiscernibilidad entre la medida y lo medido; indiscernibilidad que ahora, eterno, cumple sin resto, en el control regio del tiempo y de su fluencia. Ya no hay fluir para aquél que es puro ojos, para quien no sabe sino fijar su mirada, contemplar, ver, idear. Como aquella representancia analógica del cronómetro, los ojos detienen lo que corre y lo definen en una secuencia de instantáneas divorciadas unas de otras. A los oídos de Bergson, el tiempo real no es perceptible por la vista. Pero lo que es ciego respecto al tiempo, es sordo respecto a la eternidad. Aquel que es puro ojos no tiene tiempo, porque no hay ya duración, no hay ya ausencia, retirada, olvido: todo es presencia para aquel que es puro ojos ${ }^{25}$. Las artes mnemotécnicas - falsas maravillas - no son sino juegos de niños, ilusiones de un poder que es terrible, de aquel poder que no pierde nada porque no precisa de resguardo.

25 Jorge Martin arguye que Bergson ha sido una gran influencia también de Borges. Como veremos en el siguiente texto de Funes, el lenguaje y su arbitrariedad está subsumido a la acción y, en cambio, la intuición implicaría una suspensión de la acción a favor del conocimiento real de las cosas. Así, es gracias a la situación de inmovilidad de Funes que se activa el poder absoluto de la memoria y de la percepción. «Al quedar tullido, inmovilizado, la disposición hacia la acción desapareció en su vida; es por ello que su percepción, desinteresada, dejó de captar el aspecto útil (y, por tanto, empobrecido) de las cosas, para contemplarlas en su notable riqueza individual. De igual modo, también su cerebro se vio alterado y dejó de cumplir con una de sus funciones más importantes, que es la de inhibir aquellos recuerdos que no son útiles para la acción presente. Como la memoria acumula todo lo que la conciencia va viviendo, Funes era capaz de recordar toda su existencia pasada hasta en los más insignificantes e inservibles detalles. Despreocupado, entonces, de la acción, no teniendo en cuenta los aspectos comunes de las diversas imágenes, que le facilitarían su existencia, y recordando con infinitos detalles las diferencias entre todas las situaciones vividas anteriormente, se entiende por qué Funes era incapaz de ideas generales. De igual modo, al no actuar y no tener contacto permanente con la materia, ésta no le exigiría realizar ningún esfuerzo de concentración, y esto explicaría su incapacidad para pensar» (MARTín, J. (2005), «Borges, Funes... y Bergson», en: Variaciones Borges, 19, p. 206). Existen también lecturas más «científicas» del caso de Ireneo Funes respecto a su perfecta memoria (cf. EzouerRA, J. (2011), «Clínica y ficción: Borges y Luria acerca de la hipermnesia», en: Variaciones Borges, 32: pp. 121-133). Pero lo que me resulta interesante señalar aquí, de nuevo, es la fuerza de este viejo dogma de la metafísica occidental en la que la inmovilidad, el ocio, la contemplación, es superior a la acción. Es elocuente el verso del poema de Borges, «El Golem», cuando el Rabí se lamenta: "¿Cómo (se dijo) / pude engendrar este penoso hijo / y la inacción dejé, que es la cordura?». La vieja temática gnóstica de la ociosidad de Dios parece seguir configurando nuestros modos de comprender lo que significa una vida humana perfecta. 
«Me dijo que antes de esa tarde lluviosa en que lo volteó el azulejo, él había sido lo que son todos los cristianos: un ciego, un sordo, un abombado, un desmemoriado. (Traté de recordarle su percepción exacta del tiempo, su memoria de nombres propios; no me hizo caso). Diecinueve años había vivido como quien sueña: miraba sin ver, oía sin oír, se olvidaba de todo, de casi todo. Al caer, perdió el conocimiento; cuando lo recobró, el presente era casi intolerable de tan rico y tan nítido, y también las memorias más antiguas y más triviales. Poco después averiguó que estaba tullido. El hecho apenas le interesó. Razonó (sintió) que la inmovilidad era un precio mínimo. Ahora su percepción y su memoria eran infalibles ${ }^{26}$.

En un clima eminentemente platónico, en el reino óptico de las ideas, Funes cae para perder el conocimiento, solo para despertar al sueño (que era la vida) y contemplar por fin lo real. Como en aquel mito de Platón, en el que las almas caen a sus cuerpos bebiendo en las aguas del Leteo para poder acceder luego al conocimiento en el recuerdo de aquellas Formas vistas en su existencia premundana, Funes cae y se recobra: la verdad es por fin $a$-letheia, «no-olvido». La verdadera vida comienza, a los ojos de Funes, cuando parece haberse perdido. Solo la caída pudo regalarle la intolerable nitidez y riqueza de lo presente. Las memorias, antiguas y triviales, ya no tienen función alguna, ni lugar. Todo le es presente, y nada se le escapa, nada difiere. La inmovilidad es el precio - mínimo- que había que pagar para eludir lo fugaz, para neutralizar la oxidación, que es la esencia última de lo que existe. No le interesa, porque no hay medida de retorno para este regalo, para este gift, que lo condena a la bienaventuranza de lo presente: no había posible cálculo de ganancia para esta inversión. Una inversión que es inversión, una inversión que termina por invertir las relaciones mismas que rigen lo real y que estructuran la experiencia. La inversión alcanza a la sensación, que es ya razón («razonó (sintió)...»). La inversión alcanza el orden de la fundamentación entre la percepción y la memoria, que, infalible, las torna indiscernibles (si lo rememorado es tan vívido como lo percibido, ¿cómo distinguir uno del otro?). En otras palabras, invertir en lo absoluto es la inversión absoluta, la imposibilidad última de establecer la diferencia; es la suspensión cabal de todo diferir en la visión inmediata de lo presente. Sub specie aeternitatis. En Borges —accionista de lo arquetípico- todo es inversión: la caída es, en rigor, la erección; el sueño, la vida, y la vida, el sueño. Con Borges - este maestro de las ilusiones espectrales - entramos en el estado final de lo real que se identifica con su estado primordial, y que no es sino la borradura de todo límite, la extirpación de toda piel, el saqueo de toda muralla: con Borges - el alquimista de las letras - todo vuelve al todo, en la indeterminación de lo particular, de las partes, en la negación de la negación («omnis determinatio est negatio», rezaba Spinoza frente a sus cristales), en la indistinción de lo que

26 «Funes, el memorioso», p. 587, subrayado mío. 
difiere. Y es con Borges, también, que retrocedemos horrorizados ante la perversión de dicha inversión ${ }^{27}$.

«Nosotros, de un vistazo, percibimos tres copas en una mesa; Funes, todos los vástagos y racimos y frutos que comprende una parra. Sabía las formas de las nubes australes del amanecer del 30 de abril de 1882 y podía compararlas en el recuerdo con las vetas de un libro en pasta española que sólo había mirado una vez y con las líneas de la espuma que un remo levantó en el Río Negro la víspera de la acción del Quebracho. Esos recuerdos no eran simples; cada imagen visual estaba ligada a sensaciones musculares, térmicas, etcétera. Podía reconstruir todos los sueños, todos los entresueños. Dos o tres veces había reconstruido un día entero; no había dudado nunca, pero cada reconstrucción había requerido un día entero. Me dijo: "más recuerdos tengo yo solo que los que habrán tenido todos los hombres desde que el mundo es mundo". Y también: "Mis sueños son como la vigilia de ustedes". Y también, hacia el alba: "Mi memoria, señor, es como vaciadero de basuras". Una circunferencia en un pizarrón, un triángulo rectángulo, un rombo, son formas que podemos intuir plenamente; lo mismo le pasaba a Ireneo con las aborrascadas crines de un potro, con una punta de ganado en una cuchilla, con el fuego cambiante y con la innumerable ceniza, con las muchas caras de un muerto en un largo velorio. No sé cuántas estrellas veía en el cielo» ${ }^{28}$.

La percepción de Funes es perfecta, no deja nada en la sombra, no deja nada detrás. La diferencia entre fondo y figura se desvanece a los ojos de Funes: todo le es figura, nada se releva al fondo. Funes es una especie de super-hombre, de Zaratustra que despierta a mediodía, allí donde la luz todo lo alcanza, allí donde sombra alguna es proyectada. A una percepción perfecta le corresponde una memoria igual de poderosa. Pero si la memoria es comprendida desde las

27 Como veremos hacia el final del ensayo, esta inversión en lo absoluto muestra su misma imposibilidad. No creo que encontremos en Borges a un partidario del idealismo absoluto, sino a un hombre que, anhelando una visión de lo absoluto, muestra lo paradojal de un encuentro sin mediaciones entre lo absoluto y el singular. «As in James, I hear in Borges the rustle of an intelligence that takes delight both in grand pictures of the universe and in the paradoxes that show any such picture, however captivating, to be false» (Peters, John (2008), «Resemblance made Absolutely Exact», p. 20). En este artículo, Peters compara la filosofía idealista de Josiah Royce, para quien el Absoluto se auto-representa a sí mismo en el mundo, y donde el mapa puede ser exacto respecto al territorio en su carácter de auto-representación de un sistema, con Borges, para quien lo singular y la diferencia sigue siendo el resto necesario de toda operación de copia o de mímesis o de representación. Puede verse, en este sentido, la influencia del pragmatismo de William James en Borges. «Borges, like Kafka and Benjamin, follows the principle I have elsewhere, inverting Leibniz, called the "discernability of identicals". Even if our powers of representation were absolutely exact, a residue of difference would remain between copies» (ibid., p. 10). "Though Royce and Borges both can strike some readers as architects of suffocating idealist structures, there is a difference. Royce thinks his figure of infinity really do disclose the truth about the universe. Borges sees in such figures the paradoxes and slippages involved in any project of perfect duplication, and his skepticism about philosophical representation is designed, ultimately, to provide oxygen and exit from totalitarian systems» (ibid., p. 1).

28 «Funes, el memorioso». 
coordenadas de la percepción, y ésta a partir de la idea de presentación, entonces, una memoria perfecta es la que se acerca hasta la indistinción a la presentación perceptiva, tornando vano el sufijo en la palabra re-presentación. La memoria de Funes es ya intuición, presentación plena. Una intuición que, si bien le debe su nombre a la dimensión visual (y solemos concebir la memoria como un cinematógrafo, como un depósito de imágenes visuales), engloba la totalidad de las sensaciones concurrentes en la percepción. La memoria de Funes revive hasta el colmo de vivir, porque vuelve a sentir (¿qué significa aquí «volver»?) exactamente lo que había sentido (pero, ¿qué sentido tiene aquí conjugar en perfecto el verbo sentir?). Funes invierte un día en volver a vivir un día, y así invierte el pasado y el presente, y así invierte el sueño y la vigilia, invierte el día y la noche. En el juego de las inversiones, el día puede ser siempre el mismo, si así lo quisiera Funes ${ }^{29}$. La pesadilla trágica del eterno retorno se vuelve realidad en Funes: lo mismo puede volver, siempre el mismo. «Mis sueños son como la vigilia de ustedes», le confiesa Funes a su confidente. Pero este sueño lúcido, este dormir despierto, lleva al estado en el que lo real y su doble se confunden y entrecruzan, en un estado enfermizo, inhumano, terrible: Funes es la metáfora del insomnio, como explicó Borges.

\section{LA PERVERSIÓN DEL PLATONISMO}

Se trata de la intuición, de la inmediación. Borges parece deconstruir milenios de metafísica a partir de su ficción: ¿cómo comprendemos la vida humana bajo el paradigma de la intuición, bajo el paradigma de la inmediación? En una especie de platonismo que se quiere invertido, en una perversión del platonismo, Borges denuncia la inhumanidad de la intuición sin mediaciones, y lo denuncia a pesar de su obsesión de platonismo, a pesar de su encandilamiento por el ideal de un ojo sin párpados. La intuición se dice primeramente de los objetos del intelecto, aquellos cuya formalidad y abstracción son tan solo la cara humana de la consistencia ontológica propia de los arquetipos. Intuimos plenamente las formas: la de un rombo, la de un triángulo... no intuimos el pizarrón, sino tan solo la circunferencia que se parasita en su fondo verde. En esta predominancia de la intuición racional-intelectual que une a Platón con Spinoza, pasando por Descartes, la percepción sensorial es percepción en un sentido secundario. Podemos intuir plenamente las formas (y aquí forma se identifica con figura, en una ontología more geometrico) porque las formas no tienen profundidad, y, por ende, no ofrecen escorzo alguno. Hay intuición plena cuando la percepción alcanza todas las perspectivas posibles respecto al objeto intuido: un ojo sin perspectiva (el ojo de la razón) es el órgano de la verdad, aquél que se apropia sin resto de lo que se manifiesta. En el caso del hombre, claro, esta visión debe coincidir con una ceguera parcial, que capta solo en tanto que relega. Y si las formas abstractas pueden intuirse plenamente es, justamente, por ser abstractas, por no ser

29 La importancia de la «inversión» en la obra de Borges es subrayada por ARANGo, G. (1973), «La función del sueño en “Las ruinas circulares” de Jorge Luis Borges», p. 253, n. 29). 
reales, por ser ya constructos de la fantasía, es decir, por ser ya el resultado de un proceso de negación. Lo abstracto supone el abandono, el dejar a un lado las propiedades que hacen ser a algo un esto: la ab-stracción arranca de lo concreto su carne, su singularidad, su unicidad. La intuición es tanto más plena cuanto más vacía es. La abstracción es el paso obligado para la universalidad, que no es sino la negación de la determinación. De Spinoza a Hegel, el concepto más abstracto es, también, el más vacío, el más indeterminado. Y, paradojalmente, la intuición más plena es de lo más indeterminado, es una intuición ciega, porque no ve nada al ver todo. En el paso de lo singular a lo universal, de la carne a la figura, la intuición llega a su destino dejando una estela de cadáveres y residuos. «Mi memoria es como un vaciadero de basuras». Esta afirmación enigmática de Funes encuentra quizás sentido en este contexto: la memoria de Funes, a diferencia de la del resto de los hombres, no olvida nada, no deja nada atrás, no deja nada en la sombra, porque no conoce abstracción. Sospechaba el narrador, por ello, que Funes no era capaz de pensar, porque «pensar es olvidar diferencias, es generalizar, abstraer ${ }^{30}$. Todo lo que el hombre recuerda es aquello que sobrevive, aquello que se determina como importante en su contraste con un fondo insignificante. Funes, en cambio, recoge todo, sin distinción alguna. Lo que para todos no es sino materia anecdótica, elementos inútiles que revisten a una forma, es para Funes el contenido de su memoria. En el tejido del recuerdo, el contexto de una percepción se deja a un margen. Pero el texto de Funes no conoce márgenes; la memoria de Funes ya no discierne entre texto y con-texto. La narración de la vida es, ya, la vida misma; el mapa es su territorio.

Por la misma razón (esa razón que en su idealidad olvida su nombre, lógos, palabra), el lenguaje se quiebra a sí mismo, se vuelve in-significante, abandona su significación, su carácter de signo. El lenguaje, que en el paradigma de la intuición no es sino un cierto remedio, un cierto artificio para alcanzar el sentido formal-universal de lo concreto, pierde su utilidad. El lenguaje es la expresión de un proceso abstractivo, sella con una marca el resultado de un abandono, de un olvido, para alcanzar extensivamente lo que no puede ser comprendido en su carnalidad, en su singularidad. El concepto, fruto de este parto intelectual, supone una proporcionalidad indirecta entre su comprensión y su extensión: cuanto más universal, menos determinado. En la inversión del paradigma de la intuición que es Funes, el lenguaje es ya el pensamiento. O, mejor aún, es ya la intuición. Porque, paradojalmente, en el hombre el pensamiento se construye sobre el olvido, no puede ser intuición, no debe ser intuición plena ${ }^{31}$. El pensamiento humano es parlante, es lingüístico, es significativo. El signo remite, nos

30 «Funes, el memorioso», p. 590.

31 En este sentido, la idea de «inversión del platonismo» planteada por DeLEUZE, G.(2005), Diferencia y repetición, Buenos Aires: Amorrortu, pp. 255-261), implicaría suspender el valor de verdad del régimen de las Ideas (del orden intuitivo) respecto de la anarquía de los simulacros, sostenida sobre la ilusión de una jerarquización de las copias en el proceso fundante. Si suspendemos el valor de la intuición, entonces se desbarata todo criterio de discernimiento entre el modelo, el icono, la copia y el simulacro. 
transporta a la cosa en la construcción del resto, en la institución de una diferencia, en la postulación de un contraste entre el sentido y el sin-sentido, entre lo importante y lo in-significante. No hay significación sin resto. Un signo sin resto no es signo, y, sin embargo, en el perverso-inverso Funes, el signo deja de ser signo, porque el resto deja de ser resto, porque la «basura» es valiosa ( $\sin$ necesidad de reciclado): todo se des-barata, pues todo es importante, costoso, valioso... y por ello vale lo mismo. En Funes, la universalidad del lenguaje se suspende en pos de su referencia a-típica: la lengua no tipifica en vacío, no colecciona diferencias gracias a la identificación, ya no construye conjuntos en los que la pluralidad se hace una. La escritura, que es el arte de los tipos, la grafía de los tipos, le es por ello innecesaria, porque la esencia de la escritura es su borradura, es su destino de pérdida (a la que, como ya advertía Platón, la escritura al mismo tiempo evita y precipita) ${ }^{32}$. Las invenciones de Funes, sus sistemas de signos sin resto, no conocen escritura: «no lo había escrito, porque lo pensado una sola vez ya no podía borrársele» ${ }^{33}$.

Y, si el pensamiento es significativo, Funes no piensa, porque no olvida. Los nombres impropios de los conjuntos y colecciones son dejados a un lado por infieles, por no hacer justicia a la verdadera intuición, que es máximamente comprensiva, sin extensión alguna. Funes habla, quiere hablar, con nombres propios; Funes no habla de las cosas, sino que le habla a las cosas, a cada una por su nombre único, en el régimen de un vocativo que llama a la comparecencia inmediatamente. La singularidad irremplazable de cada fenómeno (ya decir «cosa» es proceso de un olvido previo) encuentra su correlato en signos singulares, que suspenden toda acción de re-emplazo, toda actividad de llevar las cosas de una palabra a otra impunemente. Pero el sistema de signos, cualquiera sea, es ya también abstracción por supeditar los fenómenos a las cosas, significando accidentes, circunstancias, relaciones, como si fueran predicados de algo, perdiéndolos en su especificidad (aunque aquí tampoco pueda hablarse de especies, por su carácter general). Los signos, si son significativos en tanto que pertenecen a un sistema, domestican la intuición de los fenómenos a una lógica de articulación. En una pura intuición no hay lengua, porque no hay diferencias, o mejor, porque alcanzamos la absoluta diferenciación, en el que cada signo tiene solo un referente, y dicho referente difiere de sí mismo, porque ya no hay sí mismo, no hay "cosa», sujeto o sustancia, sino puro diferir, puro fluir. Como obligaba Cratilo, hay que cortarse la lengua si queremos hablar con verdad ${ }^{34}$. Aquel sueño/pesadilla de Locke de un idioma que solo conocie-

32 Cf. Derrida, J. (1997), «La farmacia de Platón», en: La Diseminación, Madrid, Editorial Fundamentos, pp. 91-262.

33 «Funes, el memorioso», p. 588.

34 Es notable que en el poema «El Golem», Platón sea designado como el autor del «Cratilo», diálogo en el cual se intenta acceder a la naturaleza del lenguaje. Lo paradójico es que, en rigor, tanto el sucesor de Heráclito como el mismo Platón, terminen por «cortarse la lengua», uno por defecto, otro por exceso. La palabra hablada o es reflejo de un fluir al que no puede re-presentar, o es una pálida imitación de los arquetipos, a los que no puede hacer 
ra nombres propios, seguía siendo para Funes demasiado general y ambiguo, justamente porque lo propio en el nombre es ya una abstracción, una fijación arbitraria de un fenómeno, arrancándolo del tiempo y de su fluir. El intento de Funes por nombrar, no ya cada cosa, sino cada momento, le pareció igual de desechable que cualquier otro intento de construir un lenguaje que calcara lo real, y lo desecha por «la conciencia de que la tarea era interminable, la conciencia de que era inútil» ${ }^{35}$. La construcción de un idioma que fuera absolutamente fiel al mundo y a sus manifestaciones llevaría una eternidad, y, como Pierre Menard, Ireneo Funes se sabe mortal. Pero, en rigor, llevaría una eternidad y un poco más, pues implicaría el bautismo constante y diferente de cada uno de los instantes, además de los fenómenos ya pasados. Por ello, esta tarea es también inútil, tan inútil como trazar un mapa que coincidiera punto por punto con el territorio al que refiere. Aún más, todo este sueño/pesadilla, toda este elucubración insomne y desatinada, no deja de comportar una sujeción a la abstracción, pues se trata de clasificar, de ubicar lo singular en una clase, en pensar un instante como instanciación de una propiedad atemporal. Una visión absoluta, que nada pierda, no conoce instancia alguna porque no hay nada que instanciar: todo es presente, y la eternidad no es sino la borradura definitiva del límite entre el tiempo y lo atemporal ${ }^{36}$.

«Los dos proyectos que he indicado (un vocabulario infinito por la serie natural de los números, un inútil catálogo mental de todas las imágenes del recuerdo) son insensatos, pero revelan cierta balbuciente grandeza. Nos dejan vislumbrar o inferir el vertiginoso mundo de Funes. Éste, no lo olvidemos, era casi incapaz de ideas generales, platónicas. No sólo le costaba comprender que el símbolo genérico perro abarcara tantos individuos dispares de diversos tamaños y diversa forma; le molestaba que el perro de las tres y catorce (visto de perfil) tuviera el mismo nombre que el perro de las tres y cuarto (visto de frente). Su propia cara en el espejo, sus propias manos, lo sorprendían cada vez. Refiere Swift que el emperador de Lilliput discernía el movimiento del minutero; Funes discernía continuamente los tranquilos avances de la corrupción, de las caries, de la fatiga. Notaba los progresos de la muerte, de la humedad. Era el solitario y lúdico espectador de un mundo multiforme, instantáneo y casi intolerablemente preciso. Babilonia, Londres y Nueva York

justicia. Como en la frontera entre el mundo sensible y el mundo de las ideas, el lenguaje no tiene carta alguna de ciudadanía, y como ser fronterizo, es esencialmente vulnerable, indigno, sacrificable.

35 «Funes, el memorioso», p. 588-589.

36 «Locke, en el siglo XVII, postuló (y reprobó) un idioma imposible en el que cada cosa individual, cada piedra, cada pájaro y cada rama tuviera un nombre propio; Funes proyectó alguna vez un idioma análogo, pero lo desechó por parecerle demasiado general, demasiado ambiguo. En efecto, Funes no solo recordaba cada hoja de cada árbol de cada monte, sino cada una de las veces que la había percibido o imaginado. Resolvió reducir cada una de sus jornadas pretéritas a unos setenta mil recuerdos, que definiría luego por cifras. Lo disuadieron dos consideraciones: la conciencia de que la tarea era interminable, la conciencia de que era inútil. Pensó que en la hora de la muerte no habría acabado aún de clasificar todos los recuerdos de la niñez» («Funes, el memorioso», pp. 588-589, subrayado mío). 
han abrumado con feroz esplendor la imaginación de los hombres; nadie, en sus torres populosas o en sus avenidas urgentes, ha sentido el calor y la presión de una realidad tan infatigable como la que día y noche convergía sobre el infeliz Ireneo, en su pobre arrabal sudamericano. Le era muy difícil dormir. Dormir es distraerse del mundo; Funes, de espaldas en el catre, en la sombra, se figuraba cada grieta y cada moldura de las casas precisas que lo rodeaban. (Repito que el menos importante de sus recuerdos era más minucioso y más vivo que nuestra percepción de un goce físico o de un tormento físico). Hacia el Este, en un trecho no amenazado, había casas nuevas, desconocidas. Funes las imaginaba negras, compactas, hechas de tiniebla homogénea; en esa dirección volvía la cara para dormir. También solía imaginarse en el fondo del río, mecido y anulado por la corriente» ${ }^{37}$.

Son dos las veces que aparece en este texto la palabra «casi». Hay una grandeza en Funes que tan solo puede ser balbuceada, una grandeza de pequeño que ya da muestras de un futuro manejo de la lengua. Pero en estos insensatos proyectos, funestos al fin y al cabo, lo que se revela no es primeramente la grandeza, sino el balbuceo, se manifiesta no la condición de super-hombre de Funes, sino su esencial mortal finitud. Funes casi podía prescindir de las ideas generales, en un mundo que era casi preciso. La intuición de Funes, una que alcanza la percepción presente como la percepción fantasmática de la memoria, es casi absoluta. Funes se acerca a esta vissio sub specie aeternitatis, pero no deja de ser temporal, fugaz, mortal. Funes guarda el fenómeno (lo salva, como quería el viejo Aristóteles) «como si» pudiera eternizarlo, como si pudiera llevar el lenguaje de la clasificación al lenguaje arquetípico, no ya de ideas generales, ni siquiera de imágenes, sino de realidades singulares; como si el lenguaje encontrara al fin su destino fatal de tornarse tan singular como lo singular que mienta. Pero es imposible; ya nos traicionan, como a Funes, las mismas palabras. El orden de la representación no podrá ser jamás el orden de lo presente. Todo nombre propio será por fuerza impropio por ser nombre ${ }^{38}$. Y

37 «Funes, el memorioso», p. 589-590.

38 Nuño y Stewart argumentan que en Funes se nota el platonismo de Borges: «[Funes el memorioso es] una terrible y abrumadora requisitoria contra el empirismo radical, contra las tesis antiplatónicas, contra los que por huir de las ideas generales, de los universales, terminan esclavos de los registros sensoriales inmediatos» (Nuño, citado en: MARTín, J., «Borges, ¿nominalista o antinominalista?», p. 184). Sin embargo esta sola lectura no es suficiente, como intento mostrar, puesto que el postulado mismo del platonismo se pervierte en el nombre de Funes. Las cifras sin sistema son indescifrables, y las palabras sin sistema son insignificantes. Nombrar es ya sistematizar, y por tanto perder la singularidad anárquica como tal. Así, ni platonismo ni empirismo radical, sino la paradojal situación humana. «Ante la variedad infinita del universo Borges oscila entre dos planteos opuestos del problema: o se recrea en imaginar la posesión de esa riqueza que nos iguala a los dioses, o muestra su desaliento por la imposibilidad de abarcarla. Cuando sigue esta última línea empieza por afirmar nuestro fundamental desconocimiento del mundo y quizá la invalidez de la concepción unitaria de él como un objeto, lo que anula de raíz todo intento de ordenación. (...) Pero aun cuando el objeto exista, la infinitud de los matices, la fugacidad de las sensaciones, la complejidad de los elementos hacen inconcebible la tarea de registrarlos y, por otra parte, la inteligencia 
es que no puede haber propiedad, en rigor, que no sea ya nombre. El perro de las tres y catorce es el perro de las tres y cuarto porque su nombre permanece el mismo, porque es el nombre el que permite hablar de un perfil o de un frente del mismo sujeto de atribución. Ireneo no reconoce su imagen en el espejo, ni sus manos, porque cuando se ve en la falta del nombre (el fantasma por excelencia) se abre el abismo insuperable de quien ve y quien es visto. La reflexión, la vuelta sobre sí, la vuelta sobre un mismo sujeto a la largo de sus predicados, implica el nombre, la clase, la instanciación. Nunca podremos saber la sorpresa del dios aristotélico ante su espejo, pensamiento de pensamiento, que goza de una pura identidad entre su acto de pensar y el objeto de su pensamiento. Una pura identidad, digo, pero, en rigor, un puro anonimato, una pura falta de nombre. Porque el nombre habita el clivaje, la escisión, el doblez, entre quien ve y quien es visto, entre el pensamiento y lo pensado. Como en esa otra pesadilla ficcional de Boris Vian en «La hierba roja», la aniquilación de toda memoria, de toda representación, no es sino la aniquilación sin más de la subjetividad, de la identidad, de la vida. Paradojalmente, el sueño de una memoria absoluta y de un absoluto olvido coinciden en la desaparición de la diferencia, del diferir, y por tanto de la identidad. No hay identidad sin diferencia, ni diferencia sin identidad. Paradoja esencial del tiempo que fluye como un río, siempre que haya cauce, espacio delimitado del fluir. Quizá solo el fondo del río, aquél en que lo liminar parece desaparecer, represente para Funes el cumplimiento de su sueño, en su anhelo por dormir, por cerrar los ojos, y también aquellos ojos propios de la fantasía. Quizá solo en el fondo del río pueda Funes, no cerrar los ojos, sino al menos enfrentar la homogeneidad de un espacio sin objetos; quizá

humana es incapaz de penetrar la escala de valores que los ordena, si es que hay tal jerarquía. Cualquier arquitectura que se establece es en sí injusta; ya los sabios de Tlön "saben que un sistema no es otra cosa que la subordinación de todos los aspectos del universo a uno cualquiera de ellos" » (BARRENECHEA, La expresión de la irrealidad en la obra de Jorge Luis Borges, p. 75). En esta misma línea de argumentación, podemos encontrar el ensayo de Sylvia Molloy, para quien «nombrar, en la obra de Borges, implica claramente una forma de transgresión, es la vertiginosa desobediencia ante la interdicción de crear ídolos y el consiguiente desasosiego (acaso el arrepentimiento) ante el simulacro, la perversión fabricada» (Molloy, S. (1999), «Inquietud y conversión del simulacro», en: Las letras de Borges y otros ensayos, Rosario, Beatriz Viterbo Editora, p. 122). Por ello, «si se nombra, en la obra de Borges, se nombra siempre con cautela y con desvío, también con resignación: procurando no crear sino aludir. Con plena conciencia de que la alusión es otra forma — sin duda más humilde- del nombre» (p. 127). Sin embargo, al mismo tiempo, como señala la autora, la posición de Borges no puede ser taxativa: «De igual modo Borges parecería proponer, recomendar, discutir y por fin rechazar la posibilidad de suprimir el nombre que fija, peligroso e ineficaz. El rechazo de esa posibilidad —es decir, la resignada aceptación de ese nombre deficiente- se manifiesta a través del desvío, un desvío ni mayor ni menor que el que separa el ilusorio nombre original de su simulacro imperfecto» (p. 131). Claro que todo el drama de Borges solo puede explicarse dentro del paradigma de la presencia y de la transparencia, es decir, en el anhelo de que haya un Nombre que se identifique con la cosa, aun cuando dicho Lenguaje no sea accesible al hombre. Que Cratilo se corte la lengua no es sino la apoteosis del Holocausto ofrendado a la Única Lengua. 
solo en esa confusión de las aguas indistintas la escisión entre la mirada y lo mirado se pierda por fin. El sueño de la pura inmediatez, allí donde no haya mediaciones, allí donde toda mediación (que no es sino el puente de lo escindido) se resuelva en un saber absoluto, en una visión sin tiempo ni diferencia ni identidad. Pero, «en el abarrotado mundo de Funes no había sino detalles casi inmediatos ${ }^{39}$. La inmediación está vedada, traspasada, mutilada. Quizá el Espíritu de Hegel, nieto del dios metafísico de Aristóteles, sea ciego, o mejor, un Absoluto sin vida, muerto. La metafísica de la visión no puede sino desembocar en la ceguera, allí donde no hay nadie que vea ni nada por ver. Como en esa otra pesadilla ficcional de José Saramago en Ensayo sobre la ceguera, uno puede ser ciego también por exceso de luz, por una blancura lechosa que indetermina lo visible en el diluvio inclemente de una luz obscena. La perversión del platonismo (en el doble sentido de su genitivo) comienza por su reconocimiento/denegación de la ceguera. Funes es también Ireneo, nombre que misteriosamente lo conecta con el obispo de Lyon del siglo II d. C., principal adversario del gnosticismo, cuyo sueño no era sino el de alcanzar una eterna vigilia, el de lograr un absoluto saber, gracias a la participación en la vida divina ${ }^{40}$. En su nombre completo, la paz (que el nombre griego, Ireneo, refiere) choca con su apellido funesto, pero quizá sea este nombre/destino el modo de referirse a una vida sin diferencia, sin diferir, una paz, una falta de inquietud y de desazón, que es más propia de los cementerios que de las ciudades.

Si la memoria es lo que guarda, lo que preserva la identidad, es también, debe serlo, lo que la pierda, lo que la relegue al olvido. Tengo una memoria para el olvido ${ }^{41}$. El olvido no es un accidente indeseado del recuerdo, sino su vida misma. La ficción, el artificio de Funes es mortal a pesar de su intento de inmortalidad. El grito horaciano, non omnis moriar, no moriré del todo, no solo no se cumple en Funes, sino que se invierte: lo único que puede desear Funes, a contramano de sus deseos, es morir, dormir, cerrar los ojos, olvidar ${ }^{42}$. «Ireneo Funes murió en 1889 , de una congestión pulmonar» ${ }^{43}$. La primera interpretación es que dicha muerte se debe a su condición de fumador. Pero podemos también ensayar otra interpretación. Funes es mortal, y murió porque no podía

39 «Funes, el memorioso», p. 590.

40 Le debo esta conexión a Mariano García, quien me la sugirió ingeniosamente.

41 Cf. Grassi, M. (2017), «Tengo una memoria para el olvido. El interjuego entre memoria y olvido en la construccion de la identidad personal», en: Nuevo Pensamiento: Revista de Filosofia, VII/10, pp. 72-86.

42 «Entonces ví la cara de la voz que toda la noche había hablado. Ireneo tenía diecinueve años; había nacido en 1868; me pareció monumental como el bronce, más antiguo que Egipto, anterior a las profecías y a las pirámides» (OC: I, 590). Es interesante notar aquí la cercanía de las palabras de Borges con aquellas de la Oda XXX de Horacio, aquella que también expresa el deseo de inmortalidad a través de la ficción. Nuevamente, en esa indistinción entre ficción y realidad, Funes es él mismo su artificio, su constructo literario, la realización o encarnación de lo inmortal (aunque, claro, de una inmortalidad de mármol, una inmortalidad cadavérica).

43 «Funes, el memorioso», p. 590. 
respirar: su memoria lo asfixia, no hay respiración, esperanza, futuro. Respirar es dejar ir: se congestiona no solo por defecto de inspiración, sino también por incapacidad de exhalación. Retener el aire en los pulmones es también dejar de respirar. Ireneo Funes se pierde por no perderse ${ }^{44}$. A diferencia de Borges, el personaje en su «Aleph», Funes se deja llevar por la hybris, por la consecución insensata, casi irreflexiva, de su divinización, de su theosis ${ }^{45}$. No supo que su salvación era, también, perderse, ni que su perdición lo salvaría. Y es que no podemos vivir ininterrumpidamente; vivimos de las interrupciones ${ }^{46}$.

Pontificia Universidad Católica Argentina (UCA)

Martín Grassi

Facultad de Filosofía y Letras

Academia Nacional de Ciencias de Buenos Aires (ANCBA)

Consejo Nacional de Ciencia y Tecnología (CONICET - Argentina)

martingrassi@uca.edu.ar

[Artículo aprobado para publicación en enero de 2019]

${ }_{44}$ "The premature death suggests the impossibility of life with a perceptual apparatus like that of Funes (...). Moreover, the manner of his death, "congestion of the lungs", suggests the result of an overabundance of some substance that body cannot adequately dispose of or regulate. In the case of Funes, it was an overload of sensible particulars which his mind could not order or organize. The fact of Funes' early death thus suggests the implausibility of the nominalist model» (STEWART, «Borges' refutation of nominalism in Funes el memorioso», p. 83).

45 Habría que considerar en este proceso de theosis que una de las características principales de lo divino es su unidad y su unicidad, o mejor, su absoluta soledad, o falta de Otro. En esta línea, para Wright, el cuento de Borges es una alegoría y una fábula acerca de la ausencia de mutualidad, de un desuso del lenguaje que esconde una ilusión narcisística ( Jorge Luis Borges' "Funes de Memorious”", p. 48). Por ello, Wright interpreta la muerte de Ireneo Funes desde esta perspectiva: «He dies, psychosomatically, or in the realization of another metaphor, of the "congestion" of the lungs, the very organs that provide the breath of the mutual word as well as that of the single life» (p. 47). Aunque no lo he llevado a cabo aquí, sería necesario articular el paradigma de la inmediación con la imposibilidad de una relación a lo Otro, es decir, con la imposibilidad de fundamentar un «entre-nosotros», puesto que la intersubjetividad y la relación implica necesariamente un momento de mediación.

46 Los destinos pseudo divinos de Funes y de Carlos Argentino Daneri en El Aleph, muestran grotescamente el inevitable fracaso de esta especie de visión angélica del universo, así como los temas del panteísmo están unidos en Borges con el de la negación de la personalidad (cf. BARRENECHEA, La expresión de la irrealidad en la obra de Jorge Luis Borges, pp. 82-95). 